\title{
Sustainability disclosure and reputation: a comparative study
}

\author{
Giovanna Michelon* \\ University of Padova \\ Department of Economics and Management \\ Via del Santo 33 \\ 35123 Padova \\ Italy \\ e-mail: giovanna.michelon@unipd.it
}

\begin{abstract}
Drawing on legitimacy theory, we discuss that a company's reputation is a determinant of sustainability disclosure. Specifically, we consider the concept of reputation into three dimensions for analysis: stakeholders' commitment, financial performance and media exposure. This paper differs from previous social and environmental reporting studies in that it investigates both internal and external contextual factors that influence disclosure practice. We claim that companies with a good financial performance, that are adopting an active strategic position towards stakeholders and that are exposed to significant public pressure are more likely to use sustainability disclosure in order to communicate their legitimacy to operate to stakeholders. Moreover the paper analyses a wide range of corporate reports for their social and environmental content using an international sample that allows for a comparison of disclosure practices among Continental European, UK and USA companies. Our results show that stakeholder commitment and media exposure are positively associated with sustainability disclosure. Moreover, we find evidence that the drivers of disclosure vary by information type.
\end{abstract}

Keywords: Sustainability disclosure, reputation, stakeholders' commitment, market visibility, media exposure

* Giovanna Michelon is assistant professor at the School of Economics and Business of the University of Padova 


\section{Introduction}

According to legitimacy and stakeholder theories, the disclosure of financial, social and environmental information (i.e., corporate sustainability disclosure - CSD) is part of the dialogue between a company and its stakeholders and it provides information on a company's activities that help legitimise its behaviour, educate and inform, and change perceptions and expectations (Adams and Larrinaga-González, 2007; Adams and McNicholas, 2007). The possibility that the empowering potential of social and environmental reporting is being captured and institutionalised (Gray, 2002; O'Dwyer, 2003) has pointed out the need to investigate further complex and various internal contextual factors influencing disclosure practices (Adams, 2002).

The aim of this paper is to enhance our understanding of the relationship between sustainability disclosure and a company's reputation according to the legitimacy theory framework. We divide the concept of reputation into three main determinants of the extent of CSD: commitment to stakeholders (Ullmann, 1985; Unerman and Bennett, 2004), financial performance (Roberts and Dowling, 2002; Deephouse and Carter, 2005) and media exposure (Erfle and McMillan, 1990; Neu et al., 1998) and we expect that they are positively associated with the extent of CSD.

Our results support the idea that companies that are engaged with stakeholders are "more aware of the need to manage a wide range of sustainability risks and to show externally that they are doing so" (Friedman and Miles, 2001 p. 528). Moreover, our results show that media exposure is a determinant of the extent of information communicated by companies. This paper contributes to the existing literature in various ways. First of all, it provides evidence of the role played by reputation as a determinant of sustainability disclosure. 
Second, this study extends previous studies on CSD by concentrating on information released not only in annual reports, but also in stand-alone reports, such as social reports, environmental reports and sustainability reports. Third, using an international sample, we are able to compare disclosure practices in different countries. The results show differences between European and US companies with regard to the extent of disclosure. The extent of disclosure by US companies is low, while the UK, despite being considered very similar to the US as 'Anglo-Saxon' culture, is a country with high disclosure rates.

The remainder of the paper is structured as follows. The next section discusses the theoretical framework and reviews the literature on reputation according to the legitimacy theory perspective, discussing how it affects sustainability disclosure. The development of hypotheses is presented in section 3 . Section 4 describes the research method, followed by the presentation of results in section 5. Concluding remarks and suggestions for further research are presented in the last section.

\section{Theoretical Framework}

Literature has recently pointed that companies may use sustainability disclosure as a way to manage their reputation risk (Bebbington et al., 2008). Among the challenges of social and environmental reporting, Gray et al. (1995) assert that the disclosure of sustainability information serves to facilitate the projection of a socially accountable image. This will lead to increased legitimacy and will allow the company to manage reputational risks (Fombrun et al., 2000; Bebbington et al., 2008). The literature has not considered the concept of reputation as being a determinant of sustainability disclosure, even if legitimacy and reputation are somewhat overlapping concepts (Deephouse and Carter, 2005). As stated by Friedman and Miles (2001), reputation can be conceived as a determinant of 
sustainability disclosure since companies show externally that they are aware of the need for managing a wider range of social and environmental issues. Other authors, following signalling theory (Toms, 2002; Hasseldine et al., 2005), argue that companies engage in sustainability reporting as a way to signal their reputation to stakeholders. According to Gabbioneta et al. (2007, p. 99) "stakeholders tend to pay attention to actions that are perceived as salient to their specific interests and values, and make inferences about corporate dispositions (their trustworthiness, reliability, social responsibility, etc) based on observed actions that are interpreted as reflections of the former".

Reputation can be conceptualised with reference to both strategic management literature (Roberts and Dowling, 2002) and to sociological perspectives (Fombrun, 1996). From the first perspective, reputation can be defined as an organisational attribute (Roberts and Dowling, 2002) that reflects the extent to which stakeholders see the company as a good corporate citizen, and it, therefore, constitutes an intangible asset with the potential for creation of value (Little and Little, 2000). From the other perspective, reputation is a "subjective collective assessment of the trustworthiness and reliability" of companies (Fombrun and Van Riel, 1997).

Deephouse and Carter (2005) state that both reputation and legitimacy represent assessments of an organisation by a social system. They observe (2005, p. 330) that there are three areas of overlap between legitimacy and reputation. Since they are "social construction processes as stakeholders evaluate an organization", they are "linked to the same antecedents" (size, financial performance and strategic posture) and they improve the "ability to acquire resources". Nevertheless, they state that there are two important criteria for distinguishing legitimacy and reputation: "the nature of the assessment stated in the definition and the dimension on which the two concepts can be assessed" (2005, p. 331). 
While legitimacy is conceived as "the generalized perception or assumption that the actions of an entity are desirable, proper and appropriate" (Suchman, 1995, p. 573), reputation is equated to image, esteem, prestige and goodwill in developing the encompassing concept of organisational standing (Shenkar and Yuchtman-Yaar, 1997). In particular, Deephouse and Carter (2005) stress the idea that the concept of reputation recalls the relative position of an organisation among its counterparts: the relative standing of a company has to be determined through comparison with other companies. "For any two organizations, they will either have the same reputation or, more likely, one will have a better reputation than the other" (Deephouse and Carter, 2005, p. 331). Gaining a favourable reputation implies that differentiation is necessary (Fombrun, 1996), to effectively build and preserve trust and consensus requires the "capacity of simultaneously address coexisting pressures for continuous growth through wealth creating innovation and widespread expectations about appropriate strategic conduct and governance practices" (Mazzola et al., 2006, p. 385).

\section{Hypotheses Development}

As the above literature review has shown, reputation can theoretically be conceived as a determinant of CSD (Toms, 2002; Hasseldine et al., 2005; Bebbington et al., 2008). To the aim of the present study, we consider the concept of reputation along three dimensions: commitment to stakeholders, financial performance and media exposure. We choose these three dimensions because they allow us to represent i) the prestige of a company (Shenkar and Yuchtman-Yaar, 1997); ii) its strategic posture (Ullmann, 1985); iii) its relative position among its counterparts (Deephouse and Carter, 2005); iv) the extent to which stakeholders see the company as a good corporate citizen (Roberts and Dowling, 2002). 
According to Unerman and Bennett (2004), the commitment of the organization to stakeholders is essential to developing the company's legitimacy through gaining an understanding of stakeholders' expectations and "accountability should focus on addressing these social, environmental, economic and ethical expectations" (p. 685). Assuming managers are willing to reveal their social engagement to stakeholders and shareholders, one way to communicate it is through some form of disclosure. The extent to which an organisation meets the needs, expectations and demands of external constituencies beyond those required by the market (Ullmann, 1985; Belkaoui Karpik, 1989) requires the listing of all stakeholders in a company and the determination of their satisfaction. Following Suchman (1995: 574), legitimacy is "a generalized perception or assumption that actions of an entity are desirable, proper or appropriate within some socially constructed system of norms, values and beliefs". Accordingly, a company whose commitment towards the needs and expectations of stakeholders is strong and entangled will make wider use of sustainability disclosure in order to show its active strategic position (Ullmann, 1985) concerning social activities. This means that companies deal strategically with stakeholders' demands when they control resources that are critical to the company. When a company engages in socially responsible activities, which most likely involve the use of resources, it may be interpreted as a way to show their sensitivity to important influences, which do not belong to the market, but that can still be in the long-term interests of shareholders (Abbott Monsen, 1979).

Based on the above considerations, we develop the following hypothesis:

$H_{1}: \quad$ The extent of sustainability disclosure is positively related to the level of commitment of the organization to stakeholders 
On the premise that the reputation of a company is also built on its financial performance (Siltaoja, 2006; Sanchez and Sotorrì, 2007), it can be expected that companies which perform better will present higher extents of CSD, as a way to engage in dialogue with stakeholders and to sustain reputation. As stated by Friedman and Miles (2001), reputation can be conceived as a determinant of sustainability disclosure since companies show externally that they are able to sustain sound market performance, but are also aware of the need for managing a wider range of social and environmental issues. If this is the case, then the voluntary disclosure on corporate actions and outcomes should reflect their behaviour since the reputational risk they incur when communicating false information would likely have a wide and severe effect on their reputation (Roberts and Dowling, 2002). The relation between disclosure and profitability has been postulated to reflect the idea that social responsibility requires the same managerial style as that necessary to make a company profitable (Bowman and Haire, 1975).

Research has not yet found a clear relationship between CSR disclosure and financial performance, both measured using accounting and market based indicators. Belkaoui and Karpik (1989) find an insignificant negative regression coefficient, yet a positive correlation between financial performance (measured accounting return on assets and stock price return) and social disclosure. Results in Patten (1990) indicate that, at least in terms of volume, the information disclosed does impact upon stock market behaviour, but highlights no price reaction. Pava and Krausz (1996) find no evidence that companies screened on the basis of CSR criteria perform worse than other companies and they find no link to disclosure. Such inconclusive results are probably due to the unique focus on US companies, the use of old data as well as of unsophisticated measures for disclosure. In this paper, following Ullmann (1985), we assume that financial performance influences the 
financial capability to undertake costly programs related to social demands. Thus, we develop the following hypothesis:

\section{$\mathrm{H}_{2} \quad$ The extent of sustainability disclosure is positively related to the financial performance of a company}

The disclosure strategy of a company is also related to the fact that stakeholders can use other sources of information to assess and monitor the company's reputation. Recent disclosure literature emphasises the importance of media exposure and visibility (Patten, 2002; Cho and Patten, 2007) in shaping the relationship between companies and stakeholders (Brown and Deegan, 1998). Media exposure has an impact on the opinions of the general public and it helps generate public pressure (Cormier and Magnan, 2003; Brammer and Pavellin, 2004). This implies that greater media exposure has an impact on stakeholder opinions and it urges for the provision of information regarding the company's sustainability. According to Cormier and Magnan (2003), the benefits of an active reporting strategy are greater when stakeholders closely monitor a firm, because any information released can be quickly distributed at a relatively low cost to the company. Indeed, they find a positive association between environmental disclosure and media visibility, asserting that managers are more sensitive about maintaining a company's environmental reputation if it is highly visible. Hence, we develop the following research hypothesis:

$H_{3}$ : $\quad$ The extent of sustainability disclosure is positively associated with the media exposure of a company 


\section{Research method}

The research method used in the study involved the content analysis of corporate annual reports and other media from the sample of companies represented.

\section{Sample design and data collection}

The study examines the level of disclosure of 57 constituents of the Dow Jones Sustainability Index (DJSI) and of 57 companies in a control group of companies matched by country, industry and size and constituents of the Dow Jones Global Index (World1) for year 2003. We make use of a matched sample, in line with Patten (1990) and Pava and Krausz (1996), in order to control for significant differences between companies which are recognized as being socially responsible and other ad-hoc matched companies. While the measurement of social performance would require the listing of all stakeholders of a company, the determination of their satisfaction and the development of an overall index that encompasses these different criteria (Ullmann, 1985), the measure used in this study relies on the inclusion in the Dow Jones Sustainability Index, which selects companies on the basis of their economic, social and environmental performance.

We analyze disclosure behaviors in 2003, the year right after the issue of the 2002 GRI guidelines, when only few companies yet adopted this reporting framework, in order to detect whether internal motivation, rather than mimicking policies or other fashion-like motives, drives corporate sustainability disclosure.

\section{Measurement of variables}

Dependent variable - corporate sustainability disclosure 
The extent of sustainability disclosure is determined using the content analysis method; a line of research widely adopted to ensure reliability and valid inference from narrative data in compliance with their context (Krippendorff, 2004). Following coding, quantitative scales are derived to permit further analysis. In one form or another, this method has been widely adopted in previous social responsibility disclosure studies (see, e.g. Hackston and Milne, 1996). The reporting framework for the content analysis follows the guidelines of the Global Reporting Initiative (2002). The framework, following the definition of sustainability and aiming at integrating different types of disclosure, is structured as a set of indicators and elements (the total number of disclosure items is 136) belonging to three categories of information: financial, environmental and social. For each of these categories, a disclosure index was created, allowing for an analysis of disclosure by information type.

A particular sentence is chosen as the recording unit to overcome problems related to the use of words or portions of pages that add unreliability. Thus, each sentence is matched with all 136 sustainability disclosure items and is coded as follows: with a score of 0 if it provides no information; with a score of 1 if it discloses information. The level of disclosure is measured by counting the frequency of items: the same sentence can disclose more than one indicator, while if the same information is repeated in the report, this information is only considered once. The content analysis is performed using the annual social, environmental and sustainability reports of the companies (for the year 2003). We employ different measures of sustainability disclosure. $S U D$ is the total disclosure index; ECINF is the disclosure index of financial and operational information; ENVINF is the disclosure index regarding information on the environmental impact of a company's activities; SOINF is the disclosure index of the social aspects of the company's activities, 
such as labour practices, human rights, and product responsibility. We also calculate ENVSOINF which is the disclosure of only environmental and social issues. Table 1 shows the five disclosure indices and provides a short description of each.

"take in Table 1"

\section{Independent variables}

We operationalise reputation into three dimensions: commitment to stakeholders, financial performance and media exposure.

In order to measure reputation in terms of commitment to stakeholders, we employ two different variables. The first one (STAKE), aims at measuring the level of stakeholder engagement by the company. It is built using the definition of stakeholder engagement given by the G3 (GRI, 2006). Information about commitment to stakeholders was taken either from the annual report, the stand-alone reports or the company's web site. In particular, the GRI (2006) identifies four different items: i) list of stakeholder groups engaged by the company; ii) basis for identification and selection of stakeholders to engage with; iii) approaches to stakeholder engagement, including frequency of engagement by type and by stakeholder group; iv) key topics and concerns that have been raised through stakeholder engagement, and how the organisation has responded to those key topics and concerns, including through its reporting. Each item has a value equal to 1 if the company is engaging in the particular item, and 0 otherwise. The ordinal variable $S T A K E$ varies between 0 and 4 , where 0 means that the company is not engaging at all with stakeholders, and 4, where the company is committed to stakeholders.

The second reputation variable, commitment to stakeholders, aims at measuring whether the company's top level (i.e. the board of directors) takes into account the issue of stakeholder engagement. A company that implements various programs and activities at 
the board level, such as the appointment of a director or the establishment of a committee in charge of social responsibility issues, is demonstrating to society that it has an active strategic posture with regard to stakeholders (Ullmann, 1985). Such a situation is depicted by a dummy variable that equals 1 , if the company has a director in charge of social responsibility issues or if it has established a committee in charge of sustainability matters, otherwise it is 0 (CSR_BOARD).

Empirical research on the relationship between sustainability disclosure and financial performance has produced very mixed results. Previous literature has investigated both the hypothesis that social disclosure reduces investors' information uncertainty (performance based on market variables) and that it is correlated (positively) with financial performance (based on accounting variables). Hence, the financial performance in this study is measured by both accounting and market based indicators. We employ return on equity $(R O E)$ for the year 2003 and the stock price return (MKTRET) for 2003.

The availability of alternative sources of information to assess a company's commitment to stakeholders is likely to provide the company with additional societal expectations and, therefore, stakeholder monitoring. Following Cormier and Magnan (2003), we measure such monitoring using the intensity of a company's press coverage (MEDIA EXPOSURE). Data is obtained using Lexis-Nexis and from searching the world's main journals and magazines. In order for news to be considered relevant, the name of the company has to appear in the article's headline.

\section{Control variables}

We select control variables on the basis of prior studies of corporate disclosure. 
Corporate size and industry has persistently been found to be significantly and positively associated with disclosure levels (Patten, 1991; 1992; Roberts, 1992). We measure size as the logarithm of total sales (SIZE) and we control for membership in environmentally sensitive industries (BASIC MATERIALS). Another factor that has been identified as possibly influencing the level of social disclosure is the age (AGE) of the company (Roberts, 1992). Following Ahmed and Courtis (1999), we also control for leverage (LEV); measured as the ratio of total debt to shareholder equity. The companies belonging to the DJSI are selected on the basis of their financial, social and environmental performances. Therefore, we measure membership of the DJSI (DJSI) as a dummy variable equal to 1 if the company belongs to the DJSI, 0 if it does not. Finally, we control for the impact of country on disclosure by using a series of dummy variables, where USA is the omitted one. Table 2 shows the independent control variables representing the construct. All measures are defined according to what has been employed in the previous literature.

"take in Table 2"

\section{Findings}

The empirical investigation employs descriptive statistics, univariate, correlation and multivariate analysis. In particular, the ordinary least squares (OLS) technique was deemed the most suitable methodology to test the hypothesis presented in the paper. This section is dedicated to the presentation of the main findings.

\section{Descriptive statistics}

Table 3; panel A, presents descriptive statistics for the independent variables. Evidence shows that $32 \%$ of companies in the sample have a committee or a director in charge of 
social and environmental matters. On average, companies identify and select stakeholders with whom to engage, as STAKE presents a mean value of 1.22. Looking at the distribution of data we see that more than $50 \%$ of companies are not committed to stakeholders (the median value of STAKE is equal to 0 ). The mean value of ROE is equal to $19 \%$ with a standard deviation of 0.60 . This means that companies in the sample present great variability in financial performance. Such evidence is also supported by descriptive statistics for MKTRET. Companies in the sample are highly visible, since the mean value for MEDIA is 406.9. Table 3, panel B presents statistics for the control variables.

"take in Table 3"

\section{Univariate analysis}

With regard to dependent variables, descriptive statistics on the disclosure indices by information type appear in Table 4. "SUD" is the total disclosure index; the mean is 30 , which indicates that companies in the sample on average disclose 30 items (out of a highest possible score of 136). The median is 26 and the standard deviation is 18.2. "ECINF" is the disclosure index on financial and operational information (a total of 52 possible items). The mean (median) score is 14.8 (15). The standard deviation is 5.2, being the least dispersed independent variable. "ENVINF" is the disclosure index regarding information on the environmental impact of the company's activities: the mean (median) score is 6.2 (5) out of a possible score of 35. The standard deviation is 6.7. "SOINF" is the disclosure index for social aspects of the company's activities such as labour practices, human rights and product responsibility. The highest score possible is 49 ; the mean (median) value obtained is 9 (7). The standard deviation is 8.5 . 
Evidence shows that companies only provide marginal information on social and environmental issues.

"take in Table 4"

\section{Correlation Analysis}

In order to verify whether an association exists between the disclosure indices and the independent variables, a correlation analysis was performed. Such analysis also allows the identification of multicollinearity, which may lead to an underestimation of the coefficients in the regression model.

\section{"take in Table 5"}

Table 5 presents the Pearson correlations matrix between the dependent and independent variables. The correlation analysis supports our expectation that commitment to stakeholders and media exposure are positively associated with sustainability disclosure, but it does not support any relationship between disclosure and financial performance (the correlation coefficients for ROE and MKTRET are not significant). The correlation coefficients for STAKE, CSR_BOARD and MEDIA EXPOSURE are significant and are positively correlated to SUD, indicating that when a company has a strong reputation in terms of commitment to stakeholders and is exposed to public pressure (i.e. is monitored by stakeholders) then the incentives to use sustainability disclosure are higher. Table 5 also indicates the presence of multicollinearity. When independent variables provide redundant information relative to the dependent variable, the individual coefficient's significance levels are usually underestimated. In some cases, the sign of the coefficient versus the zero-order relationship is reversed. In order to ascertain whether 
relevant multicollinearity is affecting the results, the Variance Inflator Factor (VIF) was tested. The largest value among all independent variables is often used as an indicator of the severity of multicollinearity (Neter et al., 1996). A VIF value in excess of 10 is frequently an indication that multicollinearity may be unduly influencing the least square estimate. In this study, the largest VIF is equal to 3.18, so multicollinearity among the predictor variables is not a problem.

\section{Multivariate Analysis}

In order to empirically test whether an association exists between CSD and stakeholder engagement, financial performance and media exposure, the following OLS regression model was specified:

Disclosureindex $=\alpha_{0}+\alpha_{1} S T A K E+\alpha_{2} C S R_{-} B O A R D+\alpha_{3} R O E+\alpha_{4} M K T R E T+\alpha_{5} M E D I A E X P O S U R E+\alpha_{6} S I Z E+$ $\alpha_{7} A G E+\alpha_{8} B A S I C M A T E R I A L S+\alpha_{9} L E V+\alpha_{10} D J S I+\alpha_{11 i} C_{O U N T R Y_{i}}+\varepsilon$

Where:

Disclosure Index = total, financial, environmental, social disclosure indices;

STAKE $=$ commitment to stakeholders, measured by ordinal variable ranging from 0 (= no stakeholder engagement) to 4 (maximum stakeholder engagement)

CSR_BOARD = commitment to stakeholders, measured by dummy variable equal to 1 if company has a CSR/Ethics committee or director, 0 otherwise;

$\mathrm{ROE}=$ profitability, measured by return on equity

MKTRET = market profitability, measured by market return for the year 2003

MEDIA EXPOSURE = media exposure, measured by number of news stories in world publications for a particular company in 2003

SIZE = company size, measured as a logarithm of sales

AGE = company age

BASIC MATERIALS = dummy variable equals 1 if the company belongs to the basic materials sector; 0 otherwise

$\mathrm{LEV}=$ leverage, measured as Total Debt / Shareholders Equity

DJSI = reputation, measured by dummy variable equal to 1 if company belongs to the DowJones Sustainability Index in year 2003, 0 otherwise

COUNTRY $_{\mathrm{i}}=$ country dummies, equal 1 when company is from that country, 0 otherwise 
Table 6 provides the results for the multivariate regression models using the various disclosure indices.

With regard to Model 1, the regression which employs the total disclosure index, the adjusted $R^{2}$ is 0.72 and the model appears highly significant $(F=13.03, p=0.000)$. The evidence shows a positive relationship between CSR_BOARD and SUD (10\% level), indicating that when companies are committed to stakeholders' needs and expectations and they adopt a strategic, active posture on such issues, by establishing a CSR-Ethics committee at the board level, then they also communicate more information about the company's activities to stakeholders. The regression results do not provide evidence of a relationship between sustainability disclosure and financial performance, given the fact that both coefficients for ROE and MKTRET are not significant. The model also shows a positive association between MEDIA EXPOSURE and SUD, indicating that for those companies more exposed to public pressure, via appearances in news stories around the world, the disclosure on sustainability issues is higher. The evidence also supports previous findings: size and industry are positively associated with SUD. All the country dummies are significantly and positively correlated to SUD, except for Finland and Switzerland. Such findings indicate that on average, European companies disclose more sustainability information than American companies. None of the other controls are significant.

\section{"take in Table 6"}

Table 6 also reports regression results for each of the other information sub-indices. The results are statistically significant by information type. However, the amount of explained variation in disclosure ranges from $37 \%$ in the case of financial information to $74 \%$ in the case of environmental information, with social information in between at $72 \%$. Looking at 
Table 6, the same independent variables are not consistently significant across information types. In other words, different factors are important in explaining the voluntary disclosures of different types of information.

Model 2 runs the regression using ECINF as the dependent variable. This is the worst performing of all the models, as the R-squared equalled 0.37 and the F-statistics equalled 2.86. Nevertheless, the evidence shows that media exposure (MEDIA EXPOSURE) is positively associated with ECINF, supporting our research hypothesis that media exposure is a driver for disclosure. The model also shows a positive association between LEV and ECINF (5\% level). Such findings are aligned with previous evidence (Ahmed and Courtis, 1999).

Model 3 runs the regression using ENVINF as the dependent variable and it appears highly significant as the F-statistic equals 13.94; this supports our hypothesis that reputation is positively associated to ENVINF. The estimated coefficient for STAKE, CSR_BOARD and MEDIA EXPOSURE are all significant and positive, suggesting that those companies with strong commitment to stakeholders and media exposure disclose more information to stakeholders. Once again, we cannot provide evidence of a relationship between environmental disclosure and financial performance. The model shows that companies in sensitive industries, such as those in the basic materials sector, typically disclose significantly more information than companies in other industries, reflecting a greater sensitivity towards environmental issues. Indeed, five out of eight companies in this economic sector are in the $95^{\text {th }}$ percentile.

Model 4 investigates the relationship between social disclosure and the constructs for reputation. Evidence supports our hypothesis that social disclosure is positively associated with reputation, if defined in terms of commitment to stakeholders and media exposure. 
STAKE, CSR_BOARD and MEDIA EXPOSURE are positively associated with SOINF. This evidence suggests social disclosure is driven by an active strategic posture ${ }^{1}$ and by the media exposure of a company rather than by its visibility and financial performance in the market. The evidence confirms previous findings on size and industry. Surprisingly, the coefficient for AGE is significant but negative. We would have expected a positive sign since previous literature (Robert, 1992; Haniffa and Cooke, 2002) posit that reputation and history of involvement in CSR activities can become entrenched and can, therefore, raise the levels of disclosure to stakeholders. Such results may be explained by the fact that younger companies may be more sensitive to the new call for corporate social responsibility, therefore using disclosure to dialogue with stakeholders. This is consistent with the imprinting argument raised by Stinchcombe (1965). Model 4 also shows a significant difference in the disclosure level between European and US companies: US companies disclose less social information compared to their European peers.

Model 5 runs the regression using ENVSOINF as dependent variables, supporting the idea that companies with a greater reputation in terms of stakeholder engagement and media exposure are more sensitive to social and environmental accountability issues and are likely to provide a greater degree of disclosure. It also shows another important evidence: US companies seem to be less sensitive to social and environmental disclosure and present a lower incidence of each type of information. From the results, it can be inferred that, in general, European companies provide significantly more strategic and social information than American companies do. This is consistent with previous studies (Meek et al., 1995) which have found that the voluntary disclosure of non-financial information appears to be

\footnotetext{
${ }^{1}$ As STAKE is an ordinal variable, we performed also other regression models, using four different dummies, one for each stakeholder engagement item. The regression results confirm that all the stakeholders engagement items are significant and positively correlated to the level of sustainability disclosure.
} 
a particularly European phenomenon, so that both UK and Continental European companies provide more information than American companies. Furthermore, a simple mean comparison test and a one-way analysis of variance was performed to verify whether there was a significant difference in the extent of disclosure between UK and Continental European companies. However, the findings show that there is no difference in disclosure means between UK and Continental European companies.

\section{Discussion and Conclusions}

Following the theoretical debate on the relationship between reputation and CSD (Friedman and Miles, 2001; Toms, 2002; Hasseldine et al., 2005; Bebbington et al., 2008), this study empirically investigates whether there is a relationship between reputation and CSD, and it develops and tests a descriptive model on corporate sustainability disclosure in terms of commitment to stakeholders, financial performance and media exposure, after controlling for other relevant variables.

The first hypothesis aimed at verifying the relationship between sustainability disclosure and commitment to stakeholders is marginally supported by our empirical findings. In particular, the empirical test highlights how companies that consider social responsibility at the board level are more likely to present a greater extent of sustainability disclosure, even if such association is statistically significant only at the $10 \%$ level. Such a relationship holds better for the disclosure of environmental and social information. Moreover, companies that present a higher level of stakeholder engagement also seem to disclose more environmental and social information. 
The second hypothesis that aimed at verifying the relationship between sustainability disclosure and financial performance is not supported. Both measures of financial performance — profitability and market return — are not associated with the extent of CSD. This finding could be related to the fact that we do not consider a temporal lag between the measure of financial performance and the extent of CSD, whereas it could pass some time between the moment in which the company has the financial capability to undertake socially responsible programs and the moment in which it reports about them to stakeholders. Also, it could be that the willingness to disclose sustainability information is more closely related to the competitive, and not financial, performance of the company. A commitment to innovativeness, productivity, human capital, and other benchmarks of operative analysis, rather than financial performance - which is the likely outcome of good competitive performance - could be the real driver for a greater extent of CSD.

Our empirical evidence also strongly supports the third hypothesis, i.e., a positive association between disclosure and media exposure. This implies that greater media exposure urges the provision of information regarding the company's sustainability. This is the only proxy for reputation, where the association with disclosure does not vary by information type.

Such findings are relevant as they add several contributions to the existing literature on social and environmental disclosure.

First of all, they provide empirical evidence of other internal contextual factors and characteristics, besides those traditionally explored in the literature, which are related to the extent of CSD. From the results, it can be stated that companies that are committed to stakeholders, and that are monitored by stakeholders through media exposure, are more likely to disclose information on the social and environmental impact of their activities. 
The empirical evidence, therefore, supports the fact that sustainability disclosure is driven by reputation both in terms of the commitment and engagement to stakeholders and by the media visibility of the company. The more exposed a company is to the media, the more information is available for stakeholders to evaluate its commitment to social and environmental responsibility. The company, therefore, has a greater incentive to provide information on such activities.

Second, this study also provides support to previous research in showing that the role of the annual report is changing. Other types of stand-alone report are gaining importance, and companies do make use of such reports to communicate various types of information to stakeholders. This has potential implications for the focus of future research and regulatory developments in social and environmental disclosure, but also in other areas of reporting.

Third, by developing a unified, extended disclosure framework, this study supports the hypothesis that the determinants of disclosure may differ by information type. The empirical results show that financial information is mainly driven by size, leverage and media exposure, supporting the agency cost arguments that companies that are more visible and have a higher leverage disclose more information. On the other hand, environmental and social information is associated with an industry, suggesting that companies belonging to sensitive industries are more likely to disclose information about the impact of their business. Social and environmental disclosures are also positively associated to the level of stakeholder engagement and media exposure, indicating that they have incentives to disclose information regarding their social and environmental activities when they are committed to stakeholders and are monitored by them via media exposure. 
Also, with reference to social and environmental information, we see that there is also a country effect.

Indeed, the study highlights a difference in the extent of disclosure between European and American companies. In general, European companies have higher disclosure rates. The differences in CSD across different countries depend on ethical, social and environmental impacts and the political issues facing the company and its behaviour. The results of this study concur with previous research, which has highlighted variations in CSR disclosure according to the country of origin (Adams, 1999; Guthrie and Parker, 1990). This study contributes to this field of research by exploring the difference in CSD between different countries in Europe and the USA.

While American companies have developed a tradition of corporate philanthropy following a minimalist approach to social responsibility (Fisher, 2004), European companies have experienced the stronger role of the State and welfare politics and have, therefore, dealt more with the theme of workforce participation (Hutton, 2003). Such broader view of social responsibility has been defined by Fisher (2004) as the socioeconomic approach, which is more widespread in Europe than it is in the USA. According to this approach, companies serve the community, and their aim goes further than creating economic value, as their role is bound to society and to civic systems (Carroll, 1999; Fisher, 2004). As the objects of sustainability are various and aim for different goals, the disclosures also present different extents of information. It is interesting to note that the UK, despite being considered very similar to the USA as 'Anglo-Saxon' culture, is a country that presents a significantly higher extent of disclosure. 
Finally, this study, in line with previous research, provides empirical support in asserting that a company's size affects the extent of CSD, as well as membership of particularly sensitive industries.

In summary, this study investigated a descriptive model of sustainability disclosure in terms of reputation. The results suggest that the disclosure of sustainability information with regard to financial, social and environmental factors appear to be higher for (1) companies engaging with stakeholders through an active strategic stance at the board level; (2) companies experiencing strong media exposure; (3) European companies; (4) companies belonging to sensitive industries, such as those in the basic materials sector and (5) larger companies.

Further research could consider the quality (content) of disclosure, rather than the extent, in order to better disentangle the relationship between reputation and disclosure, in terms of positive or negative items of information and, therefore, different strategies of preservation or reputation building. Moreover, further analysis could verify whether companies with a strong reputation use other media to communicate to stakeholders. 


\section{References}

Abbott, W., Monsen, R. (1979) On the Measurement of Corporate Social Responsibility: Self-reported Disclosures as a Method of Measuring Corporate Social Involvement. Academy of Management Journal 22(3), 501-15.

Adams, C.A. (1999) The Nature and Processes of Corporate Reporting on Ethical Issues. CIMA Research Monograph, London.

Adams, C.A. (2002) Internal Organisational Factors Influencing Corporate Social and Ethical Reporting: Beyond Current Theorising. Accounting, Auditing and Accountability Journal 15(2), 223-50.

Adams, C.A., Larrinaga-González, C. (2007) Engaging with Organisations in Pursuit of Improved Sustainability Accounting and Performance. Accounting, Auditing and Accountability Journal 20(3), 333-55.

Adams, C.A., McNicholas P. (2007) Making a Difference: Sustainability Reporting, Accountability and Organisational Change. Accounting, Auditing and Accountability Journal 20(3), 382-402.

Ahmed, K., Courtis, J.K. (1999) Associations between Corporate Characteristics and Disclosure Levels in Annual Reports: a Meta-analysis. British Accounting Review 31(1), 35-61.

Bebbington, J., Larrinaga-González, C., Moneva, J.M. (2008) Corporate Social Responsibility and Reputation Risk Management. Accounting Auditing and Accountability Journal 21(3), 337-362

Belkaoui, A., Karpik, P.G. (1989) Determinants of the Corporate Decision to Disclose Social Information. Accounting, Auditing and Accountability Journal 2(1), 36-51.

Bowman, E.H., Haire, M. (1975) A Strategic Posture Toward Corporate Social Responsibility. California Management Review, 18(2), 49-58

Brammer. S., Pavellin, S. (2004) Voluntary Social Disclosures by Large UK Companies. Business Ethics: A European Review 13(2/3), 86-99.

Brown, N., Deegan, C. (1998) The Public Disclosure of Environmental Performance Information - a Dual Test of Media Agenda Setting Theory and Legitimacy Theory. Accounting and Business Research 29(1), 21-41.

Carroll, A.B., (1999) Corporate Social Responsibility: evolution of a definitional construct. Business and Society 38(3), 268-295.

Cho, C.H., Patten, D.M. (2007) The Role of Environmental Disclosures as Tools of Legitimacy: A Research Note. Accounting, Organizations and Society 32(7-8), 639647.

Cormier, D., Magnan, M. (2003) Environmental Reporting Management: a Continental European Perspective. Journal of Accounting and Public Policy 22(1), 43-62.

Deegan, C. (2002) The Legitimating Effect of Social and Environmental Disclosures - a Theoretical Foundation. Accounting, Auditing and Accountability Journal 15(3), 281311. 
Deephouse, D.L., Carter, S.M. (2005) An Examination of Differences Between Organizational Legitimacy and Organizational Reputation. Journal of Management Studies 42(2), 329-60.

Epstein, M.J., Birchard, B. (2000) Counting What Counts: Turning Corporate Accountability to Competitive Advantage. Perseus Books, Cambridge Massachusetts.

Erfle, S., McMillan, H. (1990) Media, Political Pressure and the Firm: the case of petroleum pricing in the late 1970s. Quarterly Journal of Economics 105(1), 115-134.

Fisher, J., (2004) Social Responsibility and Ethics: clarifying the Concepts. Journal of Business Ethics 52, 391-400

Fombrun, C. (1996) Reputation: Realizing Value from the Corporate Image. Harvard Business School Press, Boston.

Fombrun, C., Van Riel, C. (1997) The Reputational Landscape. Corporate Reputation Review 1(1-2), 5-13.

Fombrun, C.J., Gardberg N.A., Barnett M.L. (2000) Opportunity Platforms and Safety Nets: Corporate Citizenship and Reputational Risk. Business and Society Review 105(1), 85-106.

Friedman, A.L., Miles S. (2001) Socially Responsible Investment and Corporate Social and Environmental Reporting in the UK: an Exploratory Study. British Accounting Review 33(4), 523-48.

Gabbioneta, C., Ravasi, D. and Mazzola, P. (2007) Exploring the drivers of corporate reputation; A study of Italian securities analysts, Corporate Reputation Review, 10(2), 99-123.

Global Reporting Initiative (GRI) (2006) Sustainability Reporting Guidelines. www.globalreporting.org.

Gray, R. (2002) The Social Accounting Project and Accounting, Organizations and Society: Privileging Engagement, Imagination, New Accountings and Pragmatism over Critique? Accounting, Organizations and Society 27(7), 687-708.

Gray, R., Kouhy, R., Lavers, S. (1995) Corporate Social and Environmental Reporting: a Review of the Literature and a Longitudinal Study of UK Disclosure. Accounting, Auditing and Accountability 8(2), 47-77.

Guthrie, J., Parker, L.D. (1990) Corporate Social Disclosure Practice: a Comparative International Analysis. Advances in Public Interest Accounting 3, 159-75.

Hackston, D., Milne, M. (1996) Some Determinants of Social and Environmental Disclosures in New Zealand. Accounting Auditing and Accountability Journal 9(1), 77-108.

Haniffa, R.M., Cooke, T.E. (2002) Culture, Corporate Governance and Disclosure in Malaysian Corporation. Abacus 38(3), 317-49.

Hasseldine, J., Salama, A.I., Toms, J.S. (2005) Quantity versus Quality: the Impact of Environmental Disclosures on the Reputations of UK plcs. British Accounting Review $37(2), 231-48$. 
Hutton, W. (2003) The World We're In, Abacus, London.

Krippendorff, K. (2004) Content Analysis. Sage, California.

Little, P.L., Little, B.L. (2000) Do Perceptions of Corporate Social Responsibility Contribute to Explaining Differences in Corporate Price-Earnings Ratios? A research note. Corporate Reputation Review 3(2), 137-42.

Mazzola, P., Ravasi, D., Gabbioneta, C. (2006) How to Build Reputation in Financial Markets. Long Range Planning 39(4), 385-407.

Meek, G.K., Roberts, C.B., Gray, S.J. (1995) Factors Influencing Voluntary Annual Report Disclosures by US, UK and Continental European Multinational corporations. Journal of International Business Studies 26(3), 555-72.

Neter, J., Kutner, M.H., Nachtsteim, C.J., Wasserman, W. (1996) Applied Linear Statistical Models. Irwin Boston, Massachusetts.

Neu, D., Warsame, H., Pedwell, K. (1998) Managing Public Impressions: Environmental Disclosures in Annual Reports. Accounting, Organizations and Society 23(3), 265-82.

O'Dwyer, B. (2003) Conceptions of Corporate Social Responsibility: the Nature of Managerial capture. Accounting, Auditing and Accountability Journal 16(4), 523-57.

Patten D.M. (1990) The Market Reaction to Social Responsibility Disclosures: The case of the Sullivan Principles Signings. Accounting, Organizations and Society 15(6), 575-587.

Patten, D.M. (1991) Exposure, legitimacy, and social disclosure. Journal of Accounting and Public Policy 10(4), 297-308.

Patten, D.M. (1992) Intra-industry Disclosure in Response to the Alaskan oil spill: a Note on Legitimacy Theory. Accounting, Organizations and Society 17(5), 471-75.

Patten, D.M. (2002) The Relation Between Environmental Performance and Environmental Disclosure: a Research Note. Accounting, Organizations and Society 27(8), 763-773.

Pava, M.L., Krausz, J. (1996) The Association Between Corporate Social Responsibility and Financial Performance: the Paradox of Social Cost. Journal of Business Ethics $15(3), 337-47$.

Roberts, C. (1991) Environmental Disclosures: a Note on Reporting Practices in Mainland Europe. Accounting, Auditing and Accountability Journal 4(3), 62-71.

Roberts, P. W., Dowling, G. R. (2002) Corporate Reputation and Sustained Superior Financial Performance. Strategic Management Journal 23(12), 1077-93.

Roberts, R. (1992) Determinants of Corporate Social Responsibility Disclosure: an Application of Stakeholder Theory. Accounting, Organizations and Society 17(6), 595612.

Sanchez J.L.F, Sotorrìo, L.L. (2007) The Creation of Value Through Corporate Reputation. Journal of business Ethics 76(3), 335-346.

Scott, W. R. (1995) Institutions and Organizations. Sage, CA. 
Shenkar, O., Yuchtman-Yaar, E. (1997) Reputation, Image, Prestige, and Goodwill: an Interdisciplinary Approach to Organizational Standing. Human Relations 50(11), 136181 .

Siltaoja, M.E. (2006) Value Priorities as Combining Core Factors between CSR and Reputation - A qualitative study. Journal of Business Ethics 68(1), 91-111.

Stinchcombe, A. (1965) Organizations and Social Strutcure. In J.G. March (Ed.), Handbook of Organizations. Rand McNally, Illinois, 142-193.

Suchman, M. C. (1995) Managing Legitimacy: Strategic and Institutional Approaches. Academy of Management Journal 20(3), 571 - 610.

Toms, J.S. (2002) Firm Resources, Quality Signals and the Determinants of Corporate Environmental Reputation: some UK evidence. British Accounting Review 34(3), 25782.

Ullmann, A. (1985) Data in Search of a Theory: a Critical Examination of the Relationship among Social Performance, Social Disclosure, and Economic Performance. Academy of Management Review 10(3), 540-77.

Unerman, J., Bennett, M. (2004) Increased Stakeholder Dialogue and the Internet: towards Greater Corporate Accountability or Reinforcing Capitalist Hegemony? Accounting Organizations and Society 29(7), 685-707. 


\section{Tables}

\section{Table 1 Disclosure indices}

Disclosure indices by type of information

\begin{tabular}{|c|c|l|}
\hline $\begin{array}{c}\text { Disclosure index } \\
\text { ECINF }\end{array}$ & $\begin{array}{c}\text { Type of information } \\
\text { Economic }\end{array}$ & Financial and operational information and data \\
\hline ENVINF & Environmental & $\begin{array}{l}\text { Environmental impacts of companies' activities, with focus on: materials, } \\
\text { energy, water, biodiversity, emissions }\end{array}$ \\
\hline SOINF & Social & Labour practices, human rights, health and safety, product responsibility \\
\hline SOENVINF & $\begin{array}{c}\text { Social and } \\
\text { Environmental }\end{array}$ & ENVINF+SOINF \\
\hline SUD & Sustainability & ECINF+ENVINF+SOINF \\
\hline
\end{tabular}

\section{Table 2 Constructs of the independent and control variables}

\begin{tabular}{|c|c|c|}
\hline & $\begin{array}{l}\text { Independent and } \\
\text { control variables }\end{array}$ & Measurement \\
\hline $\begin{array}{l}\text { Commitment to } \\
\text { stakeholders }\end{array}$ & STAKE & $\begin{array}{l}\text { Ordinal variable ranging from } 0 \text { ( }=\text { no stakeholder engagement) } \\
\text { to } 4 \text { (maximum stakeholder engagement) }\end{array}$ \\
\hline $\begin{array}{l}\text { Commitment to } \\
\text { stakeholders }\end{array}$ & CSR_BOARD & $\begin{array}{l}\text { Dummy variable equal to } 1 \text { if company has a CSR/Ethics } \\
\text { committee or director, } 0 \text { otherwise }\end{array}$ \\
\hline Profitability & ROE & Return on equity \\
\hline Market profitability & MKTRET & Market return for the year 2003 \\
\hline Media exposure & MEDIA EXPOSURE & $\begin{array}{l}\text { Number of news stories in world publications for a particular } \\
\text { company in } 2003\end{array}$ \\
\hline Size & SIZE & Natural logarithm of net sales \\
\hline Age & AGE & Company age \\
\hline Industry & BASIC MATERIALS & $\begin{array}{l}\text { Dummy variable equal to } 1 \text { if company belongs to the basic } \\
\text { materials sector, } 0 \text { otherwise }\end{array}$ \\
\hline Leverage & LEV & Total debt / Shareholder equity \\
\hline $\begin{array}{l}\text { Membership of the } \\
\text { DowJones } \\
\text { Sustainability Index }\end{array}$ & DJSI & $\begin{array}{l}\text { Dummy variable equal to } 1 \text { if company belongs to the } \\
\text { DowJones Sustainability Index in year 2003, } 0 \text { otherwise }\end{array}$ \\
\hline Country & Country of origin & $\begin{array}{l}\text { Dummy variables referred to Denmark, Finland, France, } \\
\text { Germany, Netherlands, Spain, Sweden, Switzerland, United } \\
\text { Kingdom (USA is the omitted country) }\end{array}$ \\
\hline
\end{tabular}


Table 3 Descriptive Statistics - Independent and Control Variables

\begin{tabular}{|c|c|c|c|c|c|c|c|}
\hline $\begin{array}{l}\text { Independent } \\
\text { Variables }\end{array}$ & Mean & SD & Min & P25 & Median & P75 & Max \\
\hline STAKE & 1.22 & 1.54 & 0 & 0 & 0 & 2 & 4 \\
\hline CSR_BOARD & 0.32 & 0.47 & 0 & 0 & 0 & 1 & 1 \\
\hline ROE & 0.19 & 0.60 & -0.12 & 0.04 & 0.11 & 0.22 & 0.55 \\
\hline MKTRET & 0.26 & 0.97 & -0.52 & -0.01 & 0.13 & 0.32 & 10.05 \\
\hline MEDIA & & & & & & & \\
\hline EXPOSURE & 406.93 & 447.48 & 3 & 51 & 223 & 738 & 2181 \\
\hline \multicolumn{8}{|l|}{ PANEL B } \\
\hline $\begin{array}{l}\text { Control } \\
\text { Variables } \\
\end{array}$ & Mean & SD & Min & $\mathrm{P25}$ & Median & P75 & Max \\
\hline SIZE & 22.59 & 1.71 & 16.1 & 21.5 & 22.7 & 23.8 & 26 \\
\hline AGE & 97.92 & 61.53 & 5 & 42 & 97 & 133 & 292 \\
\hline LEV & 1.84 & 1.94 & 0 & 0.35 & 0.7 & 1.54 & 22.83 \\
\hline DJSI & 0.50 & 0.50 & 0 & 0 & 0.5 & 1 & 1 \\
\hline
\end{tabular}

STAKE $=$ commitment to stakeholders, measured by ordinal variable ranging from 0 (= no stakeholder engagement) to 4 (maximum stakeholder engagement); CSR_BOARD $=$ commitment to stakeholders, measured by dummy variable equal to 1 if company has a CSR/Ethics committee or director, 0 otherwise; $\mathrm{ROE}=$ profitability, measure as return on equity; MKTRET $=$ market profitability, measured by market return for year 2003; MEDIA EXPOSURE= media exposure, measured by number of news stories in world publications for a particular company in 2003; SIZE = company size, measured as logarithm of sales; AGE = company age; LEV = company leverage, measured as total debts/shareholders equity; DJSI = reputation, measured by dummy variable equal to 1 if company belongs to the DowJones Sustainability Index in year 2003, 0 otherwise

Table 4 Descriptive Statistics - Disclosure Indices by type of information

\begin{tabular}{lrrrrrrr} 
& Mean & \multicolumn{1}{c}{ SD } & Min & P25 & Median & P75 & Max \\
\hline \hline & & & & & & & \\
SUD & 30.096 & 18.202 & 2 & 15 & 26 & 42 & 89 \\
ENVSOINF & 15.246 & 14.531 & 0 & 3 & 10 & 24 & 66 \\
ECINF & 14.851 & 5.284 & 2 & 11 & 15 & 18 & 29 \\
ENINF & 6.246 & 6.721 & 0 & 0 & 5 & 11 & 29 \\
SOINF & 9.000 & 8.505 & 0 & 2 & 7 & 14 & 40
\end{tabular}

SUD $=$ sustainability disclosure index $;$ ENVSOINF $=$ social and environmental disclosure index $;$ ECINF $=$ company's financial and operational information disclosure index; ENVINF = company's environmental information disclosure index; SOINF = company's social information disclosure index 
Table 5

Pearson Correlation - Sig (2-tailed) N=114

MEDIA

BASIC

SUD ECINF ENVINF SOINF STAKE CSR BOARD ROE MKTRET EXPOSURE

\begin{tabular}{|c|c|c|c|c|c|c|c|c|c|c|c|c|c|}
\hline SUD & 1 & & & & & & & & & & & & \\
\hline ECINF & $0.74 * * *$ & 1 & & & & & & & & & & & \\
\hline ENVINF & $0.89 * * *$ & $0.52 * * *$ & 1 & & & & & & & & & & \\
\hline SOINF & $0.94 * * *$ & $0.62 * * *$ & $0.82 * * *$ & 1 & & & & & & & & & \\
\hline STAKE & $0.23 * *$ & 0.07 & $0.25 * * *$ & $0.28 * * *$ & 1 & & & & & & & & \\
\hline CSR_BOARD & $0.33 * * *$ & 0.13 & $0.35 * * *$ & $0.35 * * *$ & $0.22 * *$ & 1 & & & & & & & \\
\hline ROE & -0.02 & -0.02 & -0.04 & -0.01 & -0.07 & -0.04 & 1 & & & & & & \\
\hline MKTRET & -0.02 & -0.05 & 0.05 & -0.06 & -0.07 & -0.05 & -0.04 & 1 & & & & & \\
\hline MEDIA EXPOSURE & $0.75 * * *$ & $0.49 * * *$ & $0.77 * * *$ & $0.75 * * *$ & $0.24 * *$ & $0.33 * * *$ & 0.00 & 0.01 & 1 & & & & \\
\hline SI7.F & $0.32 * * *$ & $0.30 * * *$ & $0.23 * *$ & $0.33 * * *$ & 0.07 & $0.17 *$ & -0.01 & -0.07 & $0.39 * * *$ & 1 & & & \\
\hline AGE & $0.19 * *$ & $0.18^{*}$ & $0.21 * *$ & 0.14 & 0.10 & $0.16^{*}$ & 0.10 & -0.13 & $0.27 * * *$ & $0.17 *$ & 1 & & \\
\hline BASIC MATERIALS & $0.37 * * *$ & $0.21 * *$ & $0.51 * * *$ & $0.31 * * *$ & 0.11 & 0.09 & -0.06 & -0.05 & $0.30 * * *$ & -0.05 & $0.25 * * *$ & 1 & \\
\hline LEV & $0.18^{*}$ & $0.26^{* * *}$ & 0.07 & 0.15 & $0.17^{*}$ & $0.26^{* * *}$ & -0.14 & 0.00 & $0.19 * *$ & $0.25 * * *$ & $0.18^{*}$ & -0.04 & 1 \\
\hline DJSI & $0.31 * * *$ & $0.18^{*}$ & $0.27 * * *$ & $0.27 * * *$ & 0.00 & $0.20 * *$ & 0.12 & 0.08 & $0.32 * * *$ & $0.30 * * *$ & $0.19 * *$ & 0.00 & 0.00 \\
\hline
\end{tabular}

*** Correlation is significant at the 0.01 level (2-tailed).

** Correlation is significant at the 0.05 level (2-tailed).

* Correlation is significant at the 0.10 level (2-tailed).

SUD = sustainability disclosure index; ECINF = company’s financial and operational information disclosure index; ENVINF = company’s environmental information disclosure index; SOINF = company's social information disclosure index; STAKE= commitment to stakeholders, measured by ordinal variable ranging from 0 (= no stakeholder engagement) to 4 (maximum stakeholder engagement); CSR BOARD= commitment to stakeholders, measure by dummy variable equal to 1 if company has a CSR/Ethics committee or director, 0 otherwise; ROE= profitability, measure as return on equity; MKTRET= market profitability, measured by market return for year 2003; MEDIA EXPOSURE= media exposure, measured by number of news stories in world publications for a particular company in 2003; SIZE = company size, measured as logarithm of sales; AGE = company age; BASIC MATERIALS = dummy variable equals to 1 if company belongs to the Basic Materials Sector, 0 otherwise; LEV = company leverage, measured as total debts/shareholder equity; DJSI = reputation, measured by dummy variable equal to 1 if company belongs to the DowJones Sustainability Index in year 2003, 0 otherwise 
Table 6. Multiple Regressions using Different Disclosure Indices as Dependent Vari

MODEL 1 MODEL 2 MODEL 3 MODEL 4 MODEL 5

\begin{tabular}{|c|c|c|c|c|c|}
\hline & SUD & ECINF & ENVINF & SOINF & ENVSOINF \\
\hline STAKE & $\begin{array}{c}0.85 \\
(1.19)^{F}\end{array}$ & $\begin{array}{r}-0.30 \\
(0.94)\end{array}$ & $\begin{array}{r}0.56 \\
(2.18)^{* *}\end{array}$ & $\begin{array}{r}0.59 \\
(1.75)^{*}\end{array}$ & $\begin{array}{r}1.15 \\
(2.19)^{* *}\end{array}$ \\
\hline CSR_BOARD & $\begin{array}{c}3.53 \\
(1.67) * F\end{array}$ & $\begin{array}{r}-0.44 \\
(0.43)\end{array}$ & $\begin{array}{r}1.37 \\
(1.95)^{*}\end{array}$ & $\begin{array}{r}2.60 \\
(2.35) * *\end{array}$ & $\begin{array}{r}3.97 \\
(2.30) * *\end{array}$ \\
\hline ROE & $\begin{array}{c}0.01 \\
(0.51)^{F}\end{array}$ & $\begin{array}{l}0.00 \\
(0.3)\end{array}$ & $\begin{array}{c}0.00 \\
(0.01)^{F}\end{array}$ & $\begin{array}{l}0.01 \\
(0.8)\end{array}$ & $\begin{array}{r}0.01 \\
(0.52)\end{array}$ \\
\hline MKTRET & $\begin{array}{c}0.53 \\
(0.50)\end{array}$ & $\begin{array}{c}-0.17 \\
(0.35)^{F}\end{array}$ & $\begin{array}{c}0.61 \\
(1.58)^{F}\end{array}$ & $\begin{array}{c}0.09 \\
(0.18)\end{array}$ & $\begin{array}{r}0.70 \\
(0.89)\end{array}$ \\
\hline MEDIA EXPOSURE & $\begin{array}{r}0.03 \\
(8.72)^{* * *}\end{array}$ & $\begin{array}{r}0.01 \\
(3.84)^{* * * *}\end{array}$ & $\begin{array}{r}0.01 \\
(8.77)^{* * * *}\end{array}$ & $\begin{array}{r}0.01 \\
(8.24)^{* * * *}\end{array}$ & $\begin{array}{r}0.02 \\
(9.59)^{* * * *}\end{array}$ \\
\hline SIZE & $\begin{array}{r}1.95 \\
(1.75)^{*}\end{array}$ & $\begin{array}{c}0.39 \\
(1.79) * \%\end{array}$ & $\begin{array}{r}0.04 \\
(0.15)\end{array}$ & $\begin{array}{c}0.65 \\
(1.78) *\end{array}$ & $\begin{array}{r}0.69 \\
(1.21)\end{array}$ \\
\hline AGE & $\begin{array}{c}-0.03 \\
(1.44)\end{array}$ & $\begin{array}{c}0.00 \\
(0.15)^{F}\end{array}$ & $\begin{array}{r}-0.01 \\
(0.99)\end{array}$ & $\begin{array}{r}-0.02 \\
(2.16)^{* *}\end{array}$ & $\begin{array}{r}-0.03 \\
(1.87)^{*}\end{array}$ \\
\hline BASIC MATERIALS & $\begin{array}{c}17.58 \\
(3.85) * * * F\end{array}$ & $\begin{array}{r}2.73 \\
(1.35)\end{array}$ & $\begin{array}{r}8.34 \\
(5.07) * * *\end{array}$ & $\begin{array}{r}6.51 \\
(3.04)^{* * * *}\end{array}$ & $\begin{array}{r}14.85 \\
(4.44) * * *\end{array}$ \\
\hline LEV & $\begin{array}{r}0.00 \\
(0.74)\end{array}$ & $\begin{array}{c}0.00 \\
(2.19) * * F\end{array}$ & $\begin{array}{c}0.00 \\
(1.06)^{F}\end{array}$ & $\begin{array}{c}0.00 \\
(0.34)\end{array}$ & $\begin{array}{r}0.00 \\
(0.31)\end{array}$ \\
\hline DISI & $\begin{array}{c}1.55 \\
(0.70)\end{array}$ & $\begin{array}{c}0.27 \\
(0.27)^{F}\end{array}$ & $\begin{array}{c}0.64 \\
(0.81)^{F}\end{array}$ & $\begin{array}{c}0.64 \\
(0.61)\end{array}$ & $\begin{array}{r}1.28 \\
(0.79)\end{array}$ \\
\hline DENMARK & $\begin{array}{r}13.92 \\
(2.42)^{* *}\end{array}$ & $\begin{array}{c}4.64 \\
(1.83)^{*}\end{array}$ & $\begin{array}{r}2.18 \\
(1.05)\end{array}$ & $\begin{array}{r}7.10 \\
(2.63)^{* * *}\end{array}$ & $\begin{array}{r}9.28 \\
(2.20) * *\end{array}$ \\
\hline FINLAND & $\begin{array}{c}4.82 \\
(0.78)\end{array}$ & $\begin{array}{c}0.68 \\
(0.25)^{F}\end{array}$ & $\begin{array}{c}3.21 \\
(1.45)^{F}\end{array}$ & $\begin{array}{c}0.93 \\
(0.32)\end{array}$ & $\begin{array}{r}4.14 \\
(0.92)\end{array}$ \\
\hline FRANCE & $\begin{array}{c}14.66 \\
(3.46)^{* * *}=\end{array}$ & $\begin{array}{r}1.97 \\
(1.05)\end{array}$ & $\begin{array}{r}3.76 \\
(2.46)^{* *}\end{array}$ & $\begin{array}{r}8.93 \\
(4.49) * * *\end{array}$ & $\begin{array}{r}12.69 \\
(4.08) * * *\end{array}$ \\
\hline GERMANY & $\begin{array}{c}6.70 \\
(1.93) * F\end{array}$ & $\begin{array}{c}1.14 \\
(0.74)^{F}\end{array}$ & $\begin{array}{r}1.79 \\
(1.43)\end{array}$ & $\begin{array}{r}3.78 \\
(2.32)^{* * *}\end{array}$ & $\begin{array}{r}5.56 \\
(2.19) * *\end{array}$ \\
\hline NETHERLANS & $\begin{array}{c}11.88 \\
(3.01)^{* * *} F\end{array}$ & $\begin{array}{r}1.63 \\
(0.94)\end{array}$ & $\begin{array}{r}2.38 \\
(1.67) *\end{array}$ & $\begin{array}{r}7.87 \\
(4.25)^{* * *}\end{array}$ & $\begin{array}{r}10.25 \\
(3.55) * * *\end{array}$ \\
\hline SPAIN & $\begin{array}{r}22.20 \\
(2.88)^{* * * *}\end{array}$ & $\begin{array}{r}6.31 \\
(1.86) *\end{array}$ & $\begin{array}{r}5.02 \\
(1.81)^{*}\end{array}$ & $\begin{array}{r}10.87 \\
(3.01)^{* * * *}\end{array}$ & $\begin{array}{r}15.88 \\
(2.82) * * *\end{array}$ \\
\hline SWEDEN & $\begin{array}{c}11.30 \\
(1.95)^{*}\end{array}$ & $\begin{array}{c}3.61 \\
(1.41)^{F}\end{array}$ & $\begin{array}{r}2.02 \\
(0.97)\end{array}$ & $\begin{array}{r}5.67 \\
(2.09) * *\end{array}$ & $\begin{array}{r}7.69 \\
(1.81)^{*}\end{array}$ \\
\hline SWITZERLAND & $\begin{array}{r}1.96 \\
(0.35)\end{array}$ & $\begin{array}{r}-1.93 \\
(0.77)\end{array}$ & $\begin{array}{r}2.39 \\
(1.17)\end{array}$ & $\begin{array}{r}1.50 \\
(0.57)\end{array}$ & $\begin{array}{r}3.89 \\
(0.94)\end{array}$ \\
\hline UK & $\begin{array}{r}6.53 \\
(2.14)^{* *}\end{array}$ & $\begin{array}{r}0.57 \\
(0.43)\end{array}$ & $\begin{array}{r}1.50 \\
(1.36)\end{array}$ & $\begin{array}{r}4.46 \\
(3.12)^{\star * *}\end{array}$ & $\begin{array}{r}5.96 \\
(2.67)^{* * *}\end{array}$ \\
\hline Constant & $\begin{array}{l}-12.83 \\
(0.73)\end{array}$ & $\begin{array}{r}3.02 \\
(0.39)\end{array}$ & $\begin{array}{r}-1.29 \\
(0.20)\end{array}$ & $\begin{array}{r}-14.56 \\
(1.77)^{*}\end{array}$ & $\begin{array}{l}-15.85 \\
(1.23)\end{array}$ \\
\hline Observations & 114 & 114 & 1114 & 114 & $\overline{\overline{114}}$ \\
\hline R-squared & 0.72 & 0.37 & 0.74 & 0.72 & 0.77 \\
\hline$F(19,94)$ & $\begin{array}{l}13.03 \\
0.000\end{array}$ & $\begin{array}{r}2.86 \\
0.000\end{array}$ & $\begin{array}{l}13.94 \\
0.000\end{array}$ & $\begin{array}{l}12.89 \\
0.000\end{array}$ & $\begin{array}{l}16.39 \\
0.000\end{array}$ \\
\hline
\end{tabular}

Absolute value of $t$ statistics in parentheses 
SUD = sustainability disclosure index; ENVSOINF = social and environmental disclosure index; ECINF = company's financial and operational information disclosure index; ENVINF = company's environmental information disclosure index; SOINF = company's social information disclosure index; STAKE= commitment to stakeholders, measured by ordinal variable ranging from 0 (= no stakeholder engagement) to 4 (maximum stakeholder engagement); CSR_BOARD $=$ commitment to stakeholders, measure by dummy variable equal to 1 if company has a CSR/Ethics committee or director, 0 otherwise; ROE= profitability, measure as return on equity; MKTRET= market profitability, measured by market return for year 2003; MEDIA EXPOSURE= media exposure, measured by number of news stories in world publications for a particular company in 2003; SIZE = company size, measured as logarithm of sales; AGE = company age; BASIC MATERIALS = dummy variable equals to 1 if company belongs to the Basic Material Sector, 0 otherwise; LEV = company leverage, measured as total debts/shareholders equity; DJSI = reputation, measured by dummy variable equal to 1 if company belongs to the DowJones Sustainability Index in year 2003, 0 otherwise; COUNTRY DUMMIES = equal to 1 when company is from that country, 0 otherwise (USA is the omitted country) 